\title{
Effects of restricted dietary phosphorus supply to dry cows on periparturient calcium status
}

\author{
S. Wächter, ${ }^{1}{ }^{\text {I. Cohrs, }}{ }^{2}$ L. Golbeck, ${ }^{1}$ M. R. Wilkens, ${ }^{3 *}$ and W. Grünberg ${ }^{1} \dagger$ \\ ${ }^{1}$ Clinic for Cattle, University of Veterinary Medicine Hannover, Foundation, 30173 Hanover, Germany \\ ${ }^{2}$ Educational and Research Centre for Animal Husbandry, Hofgut Neumühle, 67728 Münchweiler an der Alsenz, Germany \\ ${ }^{3}$ Institute of Physiology and Cell Biology, University of Veterinary Medicine Hannover, Foundation, 30173 Hanover, Germany
}

\begin{abstract}
Restricted dietary $\mathrm{P}$ supply to transition dairy cows has recently been reported to beneficially affect the Ca balance of periparturient cows. The objective of the present study was to determine whether this effect on the $\mathrm{Ca}$ balance can be reproduced when limiting the P-restricted feeding to the last 4 wk of gestation. A total of 30 dairy cows in late pregnancy were randomly assigned to a dry cow diet with either low or adequate $\mathrm{P}$ content (0.16 and $0.30 \% \mathrm{P}$ in $\mathrm{DM}$, respectively) to be fed in the $4 \mathrm{wk}$ before expected calving. After calving, all cows received the same lactating cow ration with adequate $\mathrm{P}$ content $(0.46 \% \mathrm{P}$ in $\mathrm{DM})$. Blood was collected daily from $4 \mathrm{~d}$ antepartum until calving, at calving (d 0), 6 and $12 \mathrm{~h}$ after calving $(\mathrm{d}+0.25$ and $\mathrm{d}$ +0.5 , respectively) and on days $+1,+2,+3,+4$ and +7 relative to calving. Blood gas analyses were conducted to determine the concentration of ionized $\mathrm{Ca}$ in whole blood $\left(\left[\mathrm{Ca}^{2+}\right]\right)$, and plasma was assayed for concentrations of inorganic phosphorus $([\mathrm{Pi}])$, total calcium, parathyroid hormone ([PTH] $]$, 1,25-dihydroxyvitamin D ([1,25- $\left.\left.(\mathrm{OH})_{2} \mathrm{D}_{3}\right]\right)$, and CrossLaps ([CTX]), a biomarker for bone resorption (Immunodiagnostic Systems $\mathrm{GmbH}$ ). Repeated-measures ANOVA was conducted to study treatment, time, and lactation number effects. The mean $\left[\mathrm{Ca}^{2+}\right]$ in P-deprived cows remained above the threshold of $1.10 \mathrm{mmol} / \mathrm{L}$ throughout the study, and values were higher compared with cows on adequate $\mathrm{P}$ supply between $\mathrm{d} 0$ and $\mathrm{d}+2$ and on $\mathrm{d}+4$. The $\left[\mathrm{Ca}^{2+}\right]$ differed between treatments at the sampling times $\mathrm{d} 0, \mathrm{~d}+0.25, \mathrm{~d}+0.5, \mathrm{~d}+2$, and $\mathrm{d}+4$. Plasma $[\mathrm{PTH}]$ and $\left[1,25-(\mathrm{OH})_{2} \mathrm{D}_{3}\right]$ did not differ between treatments, but P-deprived cows had greater [CTX] than
\end{abstract}

Received May 11, 2021.

Accepted September 2, 2021.

*Current affiliation: Institute of Animal Nutrition, Nutrition Diseases and Dietetics, Faculty of Veterinary Medicine, University of Leipzig, 04103 Leipzig, Germany.

†Corresponding author: waltergruenberg@yahoo.com cows with adequate $\mathrm{P}$ supply at $\mathrm{d}+1, \mathrm{~d}+2$, and $\mathrm{d}+7$. These results indicate that restricted dietary $\mathrm{P}$ supply to during the last $4 \mathrm{wk}$ of the dry period improves the Ca homeostasis of these cows in the first days of lactation, an effect that seems to be primarily driven by increased bone tissue mobilization.

Key words: hypocalcemia, total calcium, transition cow, phosphorus deprivation

\section{INTRODUCTION}

Periparturient hypocalcemia is recognized as one of the most important metabolic disturbances of the dairy cow in early lactation (USDA, 2002). Although historically the damage associated with hypocalcemia in fresh cows was thought to primarily result from cows becoming recumbent, numerous studies published over the last decade have identified subclinical hypocalcemia (SCH), which is not easily diagnosed under field conditions and was found to be highly prevalent in dairy cows, as an important predisposing factor for common fresh cow diseases, as well as a risk factor for impaired fertility and productivity of dairy cows (Martinez et al., 2012; Venjakob et al., 2018).

The recognition of $\mathrm{SCH}$ as the main cause for economic losses associated with $\mathrm{Ca}$ balance disorders in dairy cows has led to an increased effort to improve precision of the diagnosis of $\mathrm{SCH}$, specifically focusing on identifying the most suitable time of blood sampling and to determine the most appropriate cut-off value for blood Ca concentration for diagnostic purposes (Neves et al., 2018; Venjakob et al., 2018). Common strategies for milk fever prevention were also revisited, to assess their efficiency not only in preventing periparturient recumbency but also in shortening and mitigating the periparturient phase of SCH (Kichura et al., 1982; Block, 1984; Thilsing-Hansen et al., 2002).

Most milk fever prevention strategies currently in use in the dairy industry aim at enhancing bone mobilization and intestinal $\mathrm{Ca}$ absorption through stimulation of the secretion of parathyroid hormone (PTH) and 
increasing tissue responsiveness to PTH. Approaches based on this concept include, among others, feeding Ca-deficient or low-DCAD diets during the close-up dry period, and the use of Ca binders. Recently Cohrs et al. (2018) reported that restricted dietary P supply during the transition period effectively stimulated bone mobilization, thereby releasing $\mathrm{Ca}$ and $\mathrm{P}$ from bone, and thus contributed to the mitigation of Ca balance disturbances around calving. In this study, bone mobilization around parturition was more pronounced in P-deprived cows and occurred despite markedly lower blood PTH concentrations compared with cows on adequate dietary $\mathrm{P}$ supply. Furthermore, hampered PTH secretion in P-deprived cows did not attenuate the rise of activated vitamin $\mathrm{D}_{3}$ typically observed in dairy cows around parturition (Cohrs et al., 2018). Importantly, the aforementioned study applied dietary $\mathrm{P}$ restriction throughout the transition period extending to 4 wk postpartum, which was associated with decreased DMI and milk production in early lactation in P-deprived cows. The ensuing question that remained unresolved thus far is whether limiting dietary $\mathrm{P}$ restriction strictly to the dry period would achieve the same positive effect on the Ca balance during the fresh cow period as described by Cohrs et al. (2018) under prolonged dietary $\mathrm{P}$ deprivation.

The objective of the study reported here was thus to study the effect of restricted dietary $\mathrm{P}$ supply during the last $4 \mathrm{wk}$ of gestation on the mechanisms regulating the $\mathrm{Ca}$ homeostasis, and to determine whether the results of the study by Cohrs and colleagues were reproducible in a field setting. We hypothesized that restricted supply of $\mathrm{P}$ limited to the dry period would be sufficient to obtain a significant effect on the $\mathrm{Ca}$ balance.

\section{MATERIALS AND METHODS}

\section{Ethics Statement}

The study was conducted at the Educational and Research Centre for Animal Husbandry, Hofgut Neumühle, Münchweiler an der Alsenz, Germany, from October 2019 to April 2020. All related procedures were approved by the Animal Welfare and Ethics Committee of the government of Coblenz, Rhineland Palatinate, Germany (permit no. 23-177-07/G 19-20-008).

\section{Study Design}

The experiment was conceived of as a prospective, randomized controlled study. A total of 30 late-pregnancy multiparous Holstein-Friesian dairy cows entering their second, third, or fourth lactation were blocked by lactation number (LN) and, within each block, paired by first-lactation 305-d milk yield. One cow of each pair was then randomly assigned to each of the experimental treatments, which were feeding a dry cow ration with either low $\mathrm{P}(\mathbf{L P})$ or adequate $\mathrm{P}$ content (AP). The study covered the period from 6 wk before expected calving to $\mathrm{d} 7$ postpartum, and consisted of a 2-wk acclimation period extending from 6 wk to 4 wk antepartum; an experimental feeding period during which both treatments were fed specific experimental diets, which extended from 4 wk antepartum until calving; and a postpartum observational period lasting from calving to 7 DIM (Figure 1). During acclimation, cows of both treatments were fed the AP ration while being introduced to the feed-weigh troughs and the restricted feeding protocol. During the experimental feeding period, AP cows remained on the AP ration, and LP cows were switched to the P-deficient LP dry cow diet. From calving onward, cows of both treatments were offered the same ration with adequate $\mathrm{P}$ content, formulated to meet or slightly exceed the requirements of lactating dairy cows (NRC, 2001).

\section{Animal Housing and Milking}

Late-pregnant cows from the herd of the research farm, expected to calve between November 2019 and April 2020, were included in this study. Cows were confirmed to be pregnant and determined to be healthy based on physical examination at the time of enrollment. Drying off occurred at least 8 wk before the expected calving and thus at least 2 wk before inclusion in the study.

Dry and lactating cows were housed in separated areas of a freestall barn with concrete flooring and rubber mat bedding covered with a straw-lime mixture. With approaching expected calving, dry cows were monitored closely, and a calving sensor system (Moocall Ltd.) was used to assist detection of imminent parturition at nights. Cows about to calve were moved to individual calving pens bedded with straw and each equipped with a head gate through which feed was offered. After parturition, healthy cows with good appetite and without apparent signs of disease were transferred to the lactating cow pen, generally approximately $24 \mathrm{~h}$ after calving. Lactating cows were milked twice daily between 0430 and $0530 \mathrm{~h}$ and between 1530 and $1630 \mathrm{~h}$.

\section{Feeding and Experimental Rations}

Feed was offered as TMR formulated to meet requirements of dry or lactating cows, depending on the study phase, with the exception of the dietary $\mathrm{P}$ content during the dry period (NRC, 2001). Daily feed intake 
during the dry period was restricted to $11.5 \mathrm{~kg}$ of $\mathrm{DM}$ through the use of electronic feed-weigh troughs (RIC System, Hokofarm Group). Feed restriction in combination with a low-P diet was required to prevent the daily $\mathrm{P}$ intake from exceeding $20 \mathrm{~g}$ of $\mathrm{P}$ per cow in $\mathrm{LP}$ cows, to achieve the objective of inducing a negative $\mathrm{P}$ balance during the late dry period. Feeding troughs were programmed to gradually adapt study cows to the reduced amount of feed within the first week of acclimation (Figure 1). Access to the daily dry cow ration was divided into 4 equal periods over the day to ensure an even diurnal feed consumption. Feed-weigh troughs were emptied, cleaned, and refilled once per day for dry cows and twice daily for lactating cows. Lactating cows were fed ad libitum. Daily feed consumption for each cow was recorded at the feed-weigh troughs while housed in the freestalls. Cows in individual calving pens were offered feed from individual feed bunks, and orts were weighed back manually. Water was available ad libitum.

The dry cow TMR of both treatments was based on corn silage, pressed beet pulp, hay, and straw. A pelleted concentrate specifically formulated for each treatment was added to obtain the targeted $\mathrm{P}$ content of the ration of each treatment (Table 1 ). The LP and AP rations were formulated to contain $0.15 \% \mathrm{P}$ in $\mathrm{DM}$ and $0.30 \% \mathrm{P}$ in DM, respectively. Monoammonium phosphate (Windmill Monamphos FG, Aliphos Rotterdam $\mathrm{BV}$ ) was used as $\mathrm{P}$ source in the AP ration to obtain the targeted dietary $\mathrm{P}$ content. Urea was supplemented through the pelleted concentrate of the LP ration to equalize the $\mathrm{N}$ content of both diets.

\section{Animal Health}

Activity and demeanor of study animals were observed on a daily basis, and physical examinations were conducted weekly. Animal observation was intensified during the periparturient period, with an emphasis on the detection of signs of common fresh cow disorders and, in particular, on early signs of hypocalcemia. Specifically, the general demeanor, DMI, skin and rectal temperatures, and muscle fasciculation, as well as ease of rising and standing, were monitored. Health events and related therapeutic interventions were recorded for every cow throughout the study. No standard preventive treatments such as drenches or oral Ca salt administration were performed during this study. Only plain fresh water was offered ad libitum from large buckets immediately after calving.

Cows suspected to have clinical periparturient hypocalcemia, based on the previously described indications, were checked for blood concentration of ionized Ca $\left(\left[\mathrm{Ca}^{2+}\right]\right)$ with a point of care unit as will be described and, if confirmed to be hypocalcemic, were treated with Ca salt solutions subcutaneously and orally. Samples obtained after treatment were not included in the data analysis.

\section{Sample Collection}

Feed Samples. Samples of TMR from both experimental rations were collected daily and mixed into a composited sample for each week of the study and each treatment.

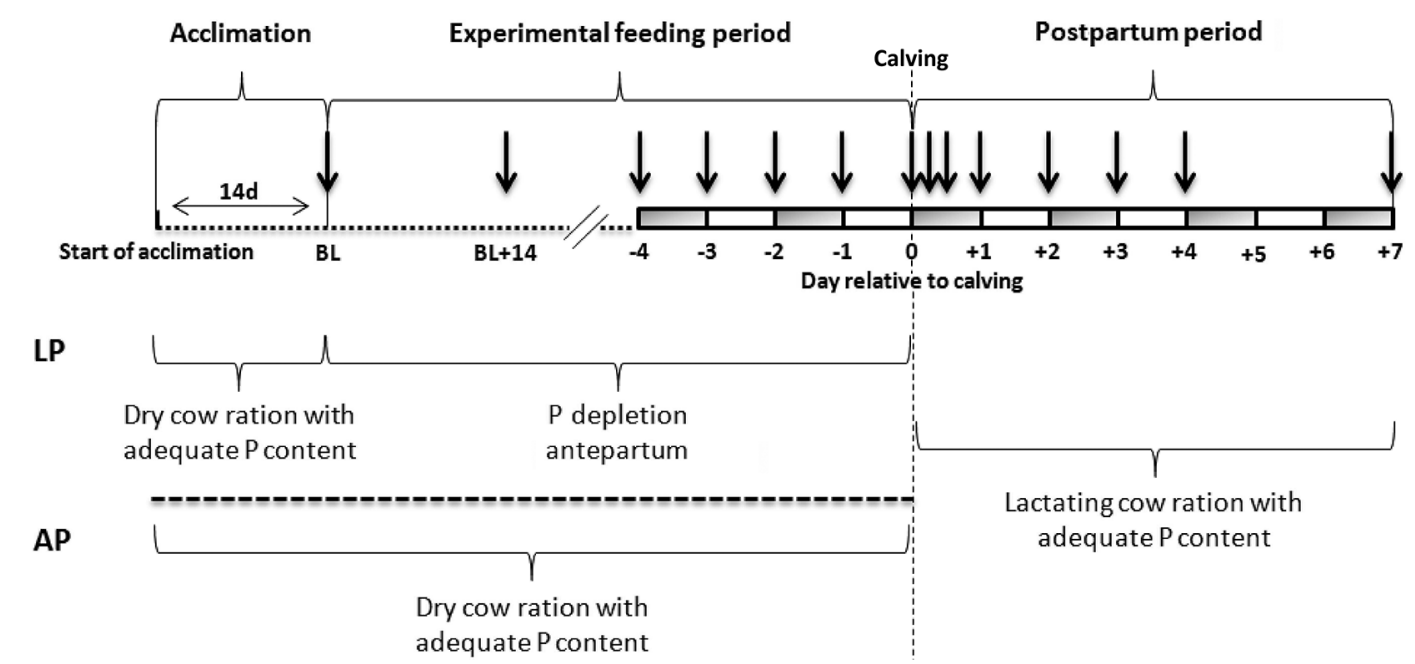

Figure 1. Outline of the study design. A total of 30 multiparous dairy cows were fed a dry cow ration with either adequate (AP, $0.30 \%$ P in $\mathrm{DM}$ ) or low $\mathrm{P}$ content (LP, $0.16 \% \mathrm{P}$ in DM) during the last 4 wk of gestation. Each shaded and open rectangle represents 1 d. Arrows mark blood sampling times. $\mathrm{BL}=$ baseline sampling time on the morning of initiating experimental feeding, after completion of the acclimation; BL $+14=$ sampling time $14 \mathrm{~d}$ after BL. 
Table 1. Ingredients (\% of DM) and composition ( $\mathrm{g} / \mathrm{kg}$ of DM, unless otherwise noted) of experimental feed rations of the adequate $\mathrm{P}(\mathrm{AP})$ and low $\mathrm{P}(\mathrm{LP})$ treatments antepartum and postpartum

\begin{tabular}{|c|c|c|c|}
\hline Item & AP antepartum & LP antepartum & Postpartum \\
\hline \multicolumn{4}{|l|}{ Ingredient } \\
\hline Corn silage & 38.3 & 38.2 & 25.5 \\
\hline Pressed pulp & 25.7 & 25.6 & 14.0 \\
\hline Hay & 8.9 & 8.9 & 5.4 \\
\hline Straw & 8.5 & 8.5 & 0 \\
\hline Grass silage & 0 & 0 & 19.5 \\
\hline Concentrate pellets ${ }^{1}$ & 18.6 & 18.8 & 0 \\
\hline Concentrate feed ${ }^{2}$ & 0 & 0 & 35.6 \\
\hline \multicolumn{4}{|l|}{ Chemical analysis } \\
\hline $\mathrm{DM}(\%$ as fed $)$ & 36.6 & 36.5 & 34.7 \\
\hline $\mathrm{NE}_{\mathrm{L}}(\mathrm{MJ} / \mathrm{kg}$ of $\mathrm{DM})$ & 5.72 & 5.68 & 6.86 \\
\hline $\mathrm{aNDF}^{3}$ & 462 & 451 & 377 \\
\hline $\mathrm{ADF}$ & 272 & 251 & 212 \\
\hline TDN & 670 & 680 & 700 \\
\hline $\mathrm{CP}$ & 120 & 117 & 168 \\
\hline $\mathrm{Ca}$ & 7.17 & 7.63 & 8.90 \\
\hline $\mathrm{K}$ & 10.9 & 11.1 & 15.3 \\
\hline $\mathrm{P}$ & 3.26 & 1.65 & 4.6 \\
\hline $\mathrm{Mg}$ & 3.67 & 3.55 & 2.6 \\
\hline S & 4.14 & 2.86 & 3.0 \\
\hline $\mathrm{Na}$ & 2.2 & 2.3 & 2.06 \\
\hline $\mathrm{Cl}$ & 4.55 & 4.67 & 4.8 \\
\hline $\mathrm{DCAD}(\mathrm{mEg} / \mathrm{kg}$ of $\mathrm{DM})$ & +50 & +40 & +160 \\
\hline
\end{tabular}

${ }^{1}$ Pelleted concentrate containing P (AP $11.0 \mathrm{~g} / \mathrm{kg}, \mathrm{LP} 1.5 \mathrm{~g} / \mathrm{kg}$ ), Ca (AP $6.5 \mathrm{~g} / \mathrm{kg}, \mathrm{LP} 7.0 \mathrm{~g} / \mathrm{kg}$ ), NH $\mathrm{NH}_{4} \mathrm{H}_{2} \mathrm{PO}_{4}$ (AP $31.3 \mathrm{~g} / \mathrm{kg}$, LP $0.0 \mathrm{~g} / \mathrm{kg}$ ), and urea (AP $19.8 \mathrm{~g} / \mathrm{kg}$, LP $33.6 \mathrm{~g} / \mathrm{kg}$ ); identical for AP and LP: Mg (13.0 g/ $\mathrm{kg})$, Na $(12.0 \mathrm{~g} / \mathrm{kg}), \mathrm{Cu}(0.09 \mathrm{~g} / \mathrm{kg})$, Co $(3.84 \mathrm{mg} / \mathrm{kg}), \mathrm{Mn}(0.266 \mathrm{~g} / \mathrm{kg}), \mathrm{Zn}(0.411 \mathrm{~g} / \mathrm{kg})$, Se $(2.04 \mathrm{mg} / \mathrm{kg})$, vitamin $\mathrm{A}(39,000 \mathrm{IU} / \mathrm{kg})$, vitamin $\mathrm{D}_{3}(6,100 \mathrm{IU} / \mathrm{kg})$, and vitamin $\mathrm{E}(0.407 \mathrm{~g} / \mathrm{kg})$.

${ }^{2}$ Concentrate feed containing P $(6.1 \mathrm{~g} / \mathrm{kg}), \mathrm{Ca}(6.5 \mathrm{~g} / \mathrm{kg}), \mathrm{Mg}(13.0 \mathrm{~g} / \mathrm{kg}), \mathrm{Na}(3.5 \mathrm{~g} / \mathrm{kg}), \mathrm{Cu}(0.034 \mathrm{~g} / \mathrm{kg})$, Co $(0.55 \mathrm{mg} / \mathrm{kg}), \mathrm{Mn}(0.133 \mathrm{~g} / \mathrm{kg}), \mathrm{Zn}(0.173 \mathrm{~g} / \mathrm{kg})$, Se $(0.93 \mathrm{mg} / \mathrm{kg})$, vitamin A $(13,800 \mathrm{IU} / \mathrm{kg})$, vitamin $\mathrm{D}_{3}$ $(2,160 \mathrm{IU} / \mathrm{kg})$, and vitamin $\mathrm{E}(0.072 \mathrm{~g} / \mathrm{kg})$

${ }^{3} \mathrm{aNDF}=\mathrm{NDF}$ analysis with amylase.

Blood Sampling. Blood samples were collected anaerobically in lithium-heparin $(\mathbf{L H})$ tubes (LH Vacuette, Greiner Bio-One) by puncture of a jugular vein. Blood was obtained at standardized times between $0800 \mathrm{~h}$ and $1000 \mathrm{~h}$ at the end of the acclimation period (baseline, BL), after 2 wk of feeding the experimental diets $(\mathrm{BL}+14)$, and daily from $4 \mathrm{~d}$ before the expected day of calving. Further blood samples were obtained immediately after calving (d 0) and 6, 12, and $24 \mathrm{~h}$ postpartum $(\mathrm{d}+0.25, \mathrm{~d}+0.5$, and $\mathrm{d}+1$, respectively) as well as on $\mathrm{d} 2,3,4$, and 7 after calving $(\mathrm{d}+2, \mathrm{~d}+3$, $\mathrm{d}+4$, and $\mathrm{d}+7$, respectively). Samples of the first 24 $\mathrm{h}$ after calving (i.e., $\mathrm{d} 0$ to $\mathrm{d}+1$ ) were taken at specific times of day to obtain the corresponding time interval in $\mathrm{h}$ relative to time of calving; samples obtained at the sampling times $\mathrm{d}+2$ to $\mathrm{d}+7$ were again obtained in the morning between $0800 \mathrm{~h}$ and $1000 \mathrm{~h}$. Blood samples obtained during the last days of gestation were retrospectively assigned a sampling time in days relative to the day of calving $(\mathrm{d}-4, \mathrm{~d}-3, \mathrm{~d}-2, \mathrm{~d}-1)$. Sampling time $\mathrm{d}-1$ was defined as the last regular blood sample obtained in the morning of the day before calving.

\section{Sample Processing and Analysis}

Feed Sample Analysis. The DM content of composited feed samples was determined by oven-drying at $100^{\circ} \mathrm{C}$ for $24 \mathrm{~h}$, and the dietary $\mathrm{P}$ content measured by inductively coupled plasma mass spectrometry. The DM content was calculated according to the formula for DM of a TMR: corrected DM content $=2.08+0.975 \times$ uncorrected DM content (Weissbach and Kuhla, 1995). The amount of fresh feed offered per day was adjusted in case of change in dietary DM content to minimize variation in the dietary $\mathrm{P}$ content.

Blood Gas Analysis. Blood gas analyses were conducted on samples obtained between $\mathrm{d}-4$ and $\mathrm{d}+7$ using a cartridge-based point of care unit to determine the $\left[\mathrm{Ca}^{2+}\right]$ in whole blood (EPOC Host and Reader, Siemens Healthineers). Before this study, the analytical performance of this unit was compared with another cartridge-based point of care unit (i-STAT, Abbott Point of Care Inc.) previously validated for the use in cattle (Yilmaz and Karapinar, 2019). For this purpose, 25 blood samples from periparturient dairy cows were 
simultaneously analyzed with both units. The results covering a $\left[\mathrm{Ca}^{2+}\right]$ range from 0.5 to $2.0 \mathrm{mmol} / \mathrm{L}$ were studied with Deming regression analysis, which yielded a strong linear correlation $(\mathrm{r}=0.996)$ between results of both units, absence of a proportional bias (slope $=$ 1.01; 95\% CI: 0.96 to 1.06), and absence of constant bias (intercept $=-0.03 ; 95 \%$ CI: -0.09 to 0.01 ). This indicates excellent agreement of results of both units with a tendency of the EPOC unit to measure $\left[\mathrm{Ca}^{2+}\right]$ in the range of $0.03 \mathrm{mmol} / \mathrm{L}$ below values determined with the i-STAT unit. The analytical range for $\left[\mathrm{Ca}^{2+}\right]$ provided by the manufacturer is 0.25 to $4.0 \mathrm{mmol} / \mathrm{L}$; the intra-assay coefficient of variation determined in our laboratory (all on one single unit, $\mathrm{n}=4 \times 10$ ) was $2.3 \%$.

Blood gas analyses were conducted on whole blood collected anaerobically in adequately filled LH tubes as described earlier, yielding blood samples with an activity of $17 \mathrm{IU}$ of heparin/mL. One milliliter of blood was aspirated anaerobically into a microliter syringe (SOFT-JECT, Henke Sass Wolf) from the evacuated LH tube. If present, air bubbles were immediately removed, and the hub of the syringe was connected to the cartridge of the point of care unit. The analysis was conducted within 5 min of sample collection.

Sample Processing. Blood remaining in the LH tubes was centrifuged at room temperature at 1,730 $\times$ $g$ for 15 min (Jouan CR422, Thermo Fisher Scientific) within 20 min of collection; plasma was harvested and stored at $-21^{\circ} \mathrm{C}$ until analysis.

Plasma Biochemical Analysis. All plasma samples were assayed for the concentrations of inorganic phosphorus ([Pi $]$, ammonium molybdate method, Cobas Mira Plus CC, Hoffmann-La Roche AG) and total calcium ([TCa], Arsenazo III method, AU 680, Beckman Coulter Inc.). The lower detection limit for TCa was $0.01 \mathrm{mmol} / \mathrm{L}$ with intra- and interassay coefficients of variation of $0.91 \%$ and $1.14 \%$, respectively.

All samples, with the exception of those obtained at $\mathrm{BL}+14, \mathrm{~d}-3, \mathrm{~d}+3$, and $\mathrm{d}+7$, were also analyzed for the plasma concentration of parathyroid hormone ([PTH], Bovine Intact PTH ELISA Kit, Immunotopics Inc.; intra- and interassay coefficients of variation and sensitivities $5.16 \%, 8.70 \%$, and $100 \mathrm{pg} / \mathrm{mL}$ ). Samples from a subset of 10 cows of each treatment were analyzed for the plasma concentrations of 1,25-dihydroxyvitamin $\mathrm{D}\left(\left[1,25-(\mathrm{OH})_{2} \mathrm{D}_{3}\right], 1,25-(\mathrm{OH})_{2}\right.$ vitamin D ELISA, Immundiagnostik $\mathrm{AG}$ ) and CrossLaps, a marker for bone resorption ([CTX], serum CrossLaps ELISA, Immunodiagnostic Systems GmbH). Intra- and interassay coefficients and sensitivities were $6.69 \%, 9.00 \%$, and $4.80 \mathrm{pg} /$ $\mathrm{mL}$ for $1,25-(\mathrm{OH})_{2} \mathrm{D}$, and $4.20 \%, 6.46 \%$, and $0.142 \mathrm{ng} /$ $\mathrm{mL}$ for CTX. Cows to be included in these subsets were selected to reflect the distribution of $\mathrm{LN}$ of the original treatment groups and to maintain equal distribution of LN between the 2 treatments. Furthermore, only cows with a complete data set were included in these subsets (i.e., cows treated for hypocalcemia were not eligible for inclusion). Specifically, these subsets were composed of 5 cows entering LN 2, 3 cows entering LN 3, and 2 cows entering LN 4 of each treatment. All samples, with the exception of those obtained at $\mathrm{BL}+14, \mathrm{~d}-3$, and $\mathrm{d}+7$ were assayed for $\left[1,25-(\mathrm{OH})_{2} \mathrm{D}_{3}\right]$, and all samples except those from $\mathrm{d}-3$ and $\mathrm{d}+3$ were analyzed for [CTX].

\section{Data Analysis}

For the purposes of this study, clinical hypocalcemia was defined as blood $\left[\mathrm{Ca}^{2+}\right]<1.10 \mathrm{mmol} / \mathrm{L}$ (Wilms et al., 2019) at any sampling time in combination with clinical signs as previously described. A cow was diagnosed with $\mathrm{SCH}$ if blood $\left[\mathrm{Ca}^{2+}\right]<1.10 \mathrm{mmol} / \mathrm{L}$ was determined at any time during the study but was not associated with apparent symptoms. Further categorization into normocalcemic $\left(\left[\mathrm{Ca}^{2+}\right]>1.10 \mathrm{mmol} / \mathrm{L}\right.$ from d 0 to $\mathrm{d}+7)$, transient hypocalcemic $\left(\left[\mathrm{Ca}^{2+}\right]<1.10\right.$ $\mathrm{mmol} / \mathrm{L}$ at at least 1 sampling time between $\mathrm{d} 0$ and $\mathrm{d}+2$, and $\left[\mathrm{Ca}^{2+}\right]>1.10 \mathrm{mmol} / \mathrm{L}$ from $\mathrm{d}+3$ to $\mathrm{d}+7$ ), chronic hypocalcemic $\left(\left[\mathrm{Ca}^{2+}\right]<1.10 \mathrm{mmol} / \mathrm{L}\right.$ at at least 1 time point between $\mathrm{d} 0$ and $\mathrm{d}+2$ combined with at least 1 time point between $\mathrm{d}+3$ to $\mathrm{d}+7$ ), and delayed hypocalcemic $\left(\left[\mathrm{Ca}^{2+}\right]>1.10 \mathrm{mmol} / \mathrm{L}\right.$ until $\mathrm{d}+2$ and $<1.10 \mathrm{mmol} / \mathrm{L}$ at at least 1 sampling time between $\mathrm{d}$ +3 and $\mathrm{d}+7$ ) was also included. This categorization, used in crude analogy to a recent publication (McArt and Neves, 2019), did not include clinically hypocalcemic animals, as they received treatment after the first occurrence of hypocalcemia.

\section{Statistical Analysis}

Results are expressed as LSM \pm SEM or as median and interquartile range for variables not meeting the assumption of normality. The statistical significance level was set at $P<0.05$. Normality of residuals and homogeneity of variance were examined (Shapiro-Wilk test); variables violating the assumption of normal distribution were subject to log-transformation. Associations between categorical variables (categories of hypocalcemia and treatment) were tested with chi-squared statistics using PROC FREQ (SAS version 9.4, SAS Institute Inc.).

Repeated-measures ANOVA with animal identification number as subject was used to determine fixed effects of treatment, time, LN with time as repeated factor, and the interaction between treatment and time, 
using PROC MIXED. The most appropriate covariance structure was chosen based on the lowest Akaike information criterion. Bonferroni-adjusted $P$-values were used to assess differences between treatments at specific sampling times whenever the $F$-test was significant.

The required sample size for this study was estimated on the basis of results obtained from an earlier study investigating the effects of dietary $\mathrm{P}$ deprivation in mid-lactation dairy cows (Grünberg et al., 2015; Grünberg et al., 2019). We anticipated a difference in plasma [TCa] of $20 \%$, or approximately $0.4 \mathrm{mmol} / \mathrm{L}$, between treatments around parturition with a standard deviation of $10 \%$, and furthermore anticipated a $15 \%$ dropout rate due to early periparturient disease potentially exacerbated by $\mathrm{P}$ deprivation. Fifteen cows by treatment provided $80 \%$ power while controlling for a $5 \%$ type I error to identify the effect size mentioned previously. All analyses were conducted with SAS software, version 9.4.

\section{RESULTS}

\section{Animals and Feeding}

Of the 30 cows included in the study, 7 and 8 cows assigned to the AP and LP treatments, respectively, entered the second lactation, 5 and 4 cows entered the third lactation, and 3 cows of each treatment entered the fourth lactation. Mean ( \pm SD) BW was $775 \pm$ $73 \mathrm{~kg}$ and $764 \pm 82 \mathrm{~kg}$ for AP and LP, respectively, with no difference between treatments in LN and BW. Experimental rations were fed for at least $20 \mathrm{~d}$, with durations ranging from 20 to $45 \mathrm{~d}(30 \pm 6 \mathrm{~d})$ for $\mathrm{AP}$ and from 26 to $43 \mathrm{~d}(32 \pm 4 \mathrm{~d})$ for LP; these time spans did not differ between treatments. Analyses of the experimental rations throughout the study yielded mean P contents of $0.30 \pm 0.05 \%$ and $0.16 \pm 0.01 \% \mathrm{P}$ in DM for dry cow AP and LP rations, respectively. The average $\mathrm{P}$ content of the lactation cow ration was $0.46 \% \mathrm{P}$ in DM.

A total of 26 cows calved spontaneously; 3 AP cows and $1 \mathrm{LP}$ cow required calving assistance. Of these, 29 calves were born alive, and 1 calf belonging to an AP cow was stillborn.

Stage 1 clinical hypocalcemia (Constable et al., 2016a) was diagnosed in 3 AP cows ( 1 and 2 cows of LN 3 and LN 4, respectively) and 1 LP cow (LN 3). Clinical hypocalcemia occurred at $\mathrm{d}+0.25 \mathrm{~d}+1$, and $\mathrm{d}+4$ in the $3 \mathrm{AP}$ cows, and at $\mathrm{d}+7$ in the $1 \mathrm{LP}$ cow. Clinical signs resolved within $24 \mathrm{~h}$ of treatment.

One LP cow developed clinical signs of acute rumen acidosis $3 \mathrm{~d}$ postpartum after engorging $22 \mathrm{~kg}$ of DM immediately after calving when switched from restrict- ed feeding of the dry cow ration to ad libitum feeding of the lactating cow ration. Because this animal required therapeutic intervention, it was prematurely released from the study on $d+3$. Data obtained from this cow until sampling time $\mathrm{d}+2$ were included in the analysis.

\section{Blood and Plasma Biochemical Analysis}

The maximum deviation from the scheduled time of blood sampling was $+40 \mathrm{~min}$ for $\mathrm{d} 0,-5$ to $+5 \mathrm{~min}$ for $\mathrm{d}+0.25,-10$ to $+5 \min$ for $\mathrm{d}+0.5$, and -15 to $+5 \mathrm{~min}$ for $\mathrm{d}+1$.

Plasma [Pi]-time curves stratified by treatment are presented in Figure 2. The ANOVA revealed a treatment $(P=0.0003)$, time $(P<0.0001)$, and treatment $\times$ time interaction effect $(P<0.0001)$ but neither an LN nor a treatment $\times \mathrm{LN}$ interaction effect. Plasma [Pi] did not differ between treatments at BL $(1.80 \pm 0.08$ and 1.76 $\pm 0.08 \mathrm{mmol} / \mathrm{L}$ for $\mathrm{AP}$ and $\mathrm{LP}$, respectively). The LP cows had lower plasma $[\mathrm{Pi}]$ than AP cows from $\mathrm{d}-4$ until $\mathrm{d}+1$. A pronounced drop of plasma [Pi] occurred in the last $24 \mathrm{~h}$ before calving in both treatments, with a nadir of $0.6 \mathrm{mmol} / \mathrm{L}$ for $\mathrm{LP}$ and $0.9 \mathrm{mmol} / \mathrm{L}$ for AP cows reached at $\mathrm{d} 0$ (Figure 2). The mean plasma [Pi] increased again in both treatments from the moment of calving until $\mathrm{d}+3$.

Blood $\left[\mathrm{Ca}^{2+}\right]$-time curves stratified by treatment are presented in Figure 3. This parameter showed treatment $(P=0.001)$, time $(P<0.0001)$, LN $(P=0.009)$, and treatment $\times$ time interaction effects $(P=0.009)$. Values of LP cows were numerically higher than those of AP cows on the last $4 \mathrm{~d}$ before calving; differences were statistically significant from $\mathrm{d} 0$ to $\mathrm{d}+2$ and on $\mathrm{d}$ +4 . For AP cows the mean $\left[\mathrm{Ca}^{2+}\right]$ was below the threshold of $1.10 \mathrm{mmol} / \mathrm{L}$ at all sampling times between $\mathrm{d}$ 0 and $\mathrm{d}+2$, whereas for LP cows this value did not fall below $1.10 \mathrm{mmol} / \mathrm{L}$ at any point during the entire observation period (Figure 3). Blood $\left[\mathrm{Ca}^{2+}\right]$ reached its nadir at $\mathrm{d}+0.25$ in both treatments. The LN effect was reflected in lower $\left[\mathrm{Ca}^{2+}\right]$ for LN 4 compared with LN 2 .

In 10 of the $12 \mathrm{AP}$ cows $(5,4$, and 1 cows of LN 2, 3 , and 4 , respectively) and 8 of $14 \mathrm{LP}$ cows $(3,2$, and 3 cows of LN 2, 3, and 4, respectively) without clinical signs of hypocalcemia, blood $\left[\mathrm{Ca}^{2+}\right]<1.10 \mathrm{mmol} / \mathrm{L}$ was measured at at least 1 sampling point. Two of $15 \mathrm{AP}$ cows and six of $15 \mathrm{LP}$ cows remained normocalcemic throughout the study, a numerical difference that did not reach the level of statistical significance. Of the subclinically hypocalcemic cows, 4 AP and 6 LP cows were categorized as transient hypocalcemic, whereas 5 AP cows fell into the category of chronic hypocalcemia and 1 cow each of the AP and LP treatment into the category of delayed hypocalcemia. 
Figure 4 depicts the concentration-time curves for plasma TCa stratified by treatment. A treatment $(P=$ $0.004)$ and time effect $(P<0.0001)$ but no LN, treatment $\times$ time interaction or treatment $\times \mathrm{LN}$ interaction effects were apparent. The mean [TCa] of AP cows was statistically significantly below values of LP cows at the time points $\mathrm{d}+0.25, \mathrm{~d}+0.5, \mathrm{~d}+2$, and $\mathrm{d}+4$, with values reaching their nadir at $\mathrm{d}+0.25$ and $\mathrm{d}+1$ in $\mathrm{AP}$ and LP cows, respectively (Figure 4).

Values for plasma $[\mathrm{CTX}]$, $[\mathrm{PTH}]$, and $\left[1,25-(\mathrm{OH})_{2} \mathrm{D}_{3}\right]$ stratified by treatment and time are summarized in Table 2. Plasma $[\mathrm{CTX}]$ showed a treatment $(P=0.05)$, time $(P<0.0001)$, and treatment $\times$ time interaction $(P=0.04)$ effect but neither an LN nor a treatment $\times$ LN interaction effect (Table 2). The LP cows had higher values than AP cows at $\mathrm{d}+1, \mathrm{~d}+2$, and $\mathrm{d}+7$, while similar concentration ranges were measured in both treatments antepartum. For $[\mathrm{PTH}]$ time $(P=$ $0.0002)$ and $\mathrm{LN}(P=0.007)$ effects but neither a treatment nor a treatment $\times$ time interaction effect could be identified. This parameter was characterized by a large between- and within-animal variation; a retrospective power analysis indicated that the samples size was insufficient to reach significance level for the observed numerical difference between treatments for this parameter. Plasma $[\mathrm{PTH}]$ increased around parturition in cows of both treatments, with no indication of higher PTH concentrations in LP than in AP cows. Plasma $[\mathrm{PTH}]$ of older cows in LN 4 were higher than of cows in LN $2(P=0.003)$. A significant time effect $(P<$ $0.0001)$ was observed for plasma $\left[1,25-(\mathrm{OH})_{2} \mathrm{D}_{3}\right]$ with values increasing between $\mathrm{d} 0$ and $\mathrm{d}+2$ in both treatments (Table 2). No treatment, LN, treatment $\times$ time interaction, or treatment $\times$ LN interaction effect was found. Numerical differences between treatments were observed only at $\mathrm{d}+0.5$ and $\mathrm{d}+1$, with higher values in AP compared with LP cows (Table 2).

\section{DISCUSSION}

The objective of this study was to determine whether a feeding protocol restricting the dietary $\mathrm{P}$ supply during the last $4 \mathrm{wk}$ of the dry period was effective in improving the $\mathrm{Ca}$ homeostasis of high-yielding

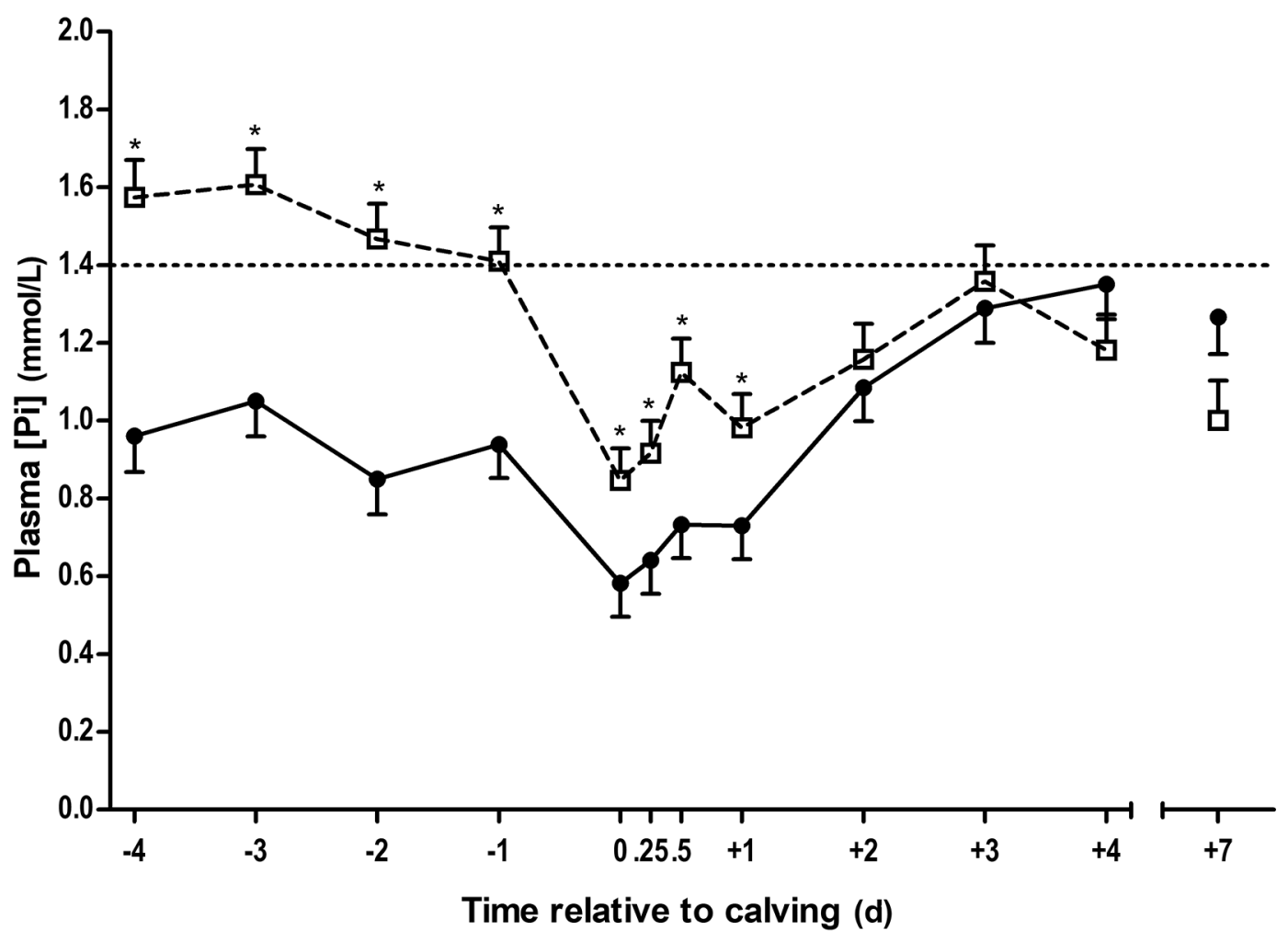

Figure 2. Least squares means ( \pm SEM) of plasma inorganic $\mathrm{P}$ concentration ([Pi]) for adequate $\mathrm{P}$ (AP, dashed line, open squares) and low $\mathrm{P}$ (LP, solid line, closed circles) treatments. The horizontal dotted line represents the lower reference range for plasma [Pi] in cattle (Constable et al., 2016b). Each treatment comprised 15 multiparous dairy cows fed a dry cow ration with either adequate (AP, $0.30 \% \mathrm{P}$ in DM) or low $\mathrm{P}$ content (LP, $0.16 \% \mathrm{P}$ in DM) during the last $4 \mathrm{wk}$ of gestation. Time points labeled with an asterisk differ significantly between treatments $(P$ $<0.05)$. 


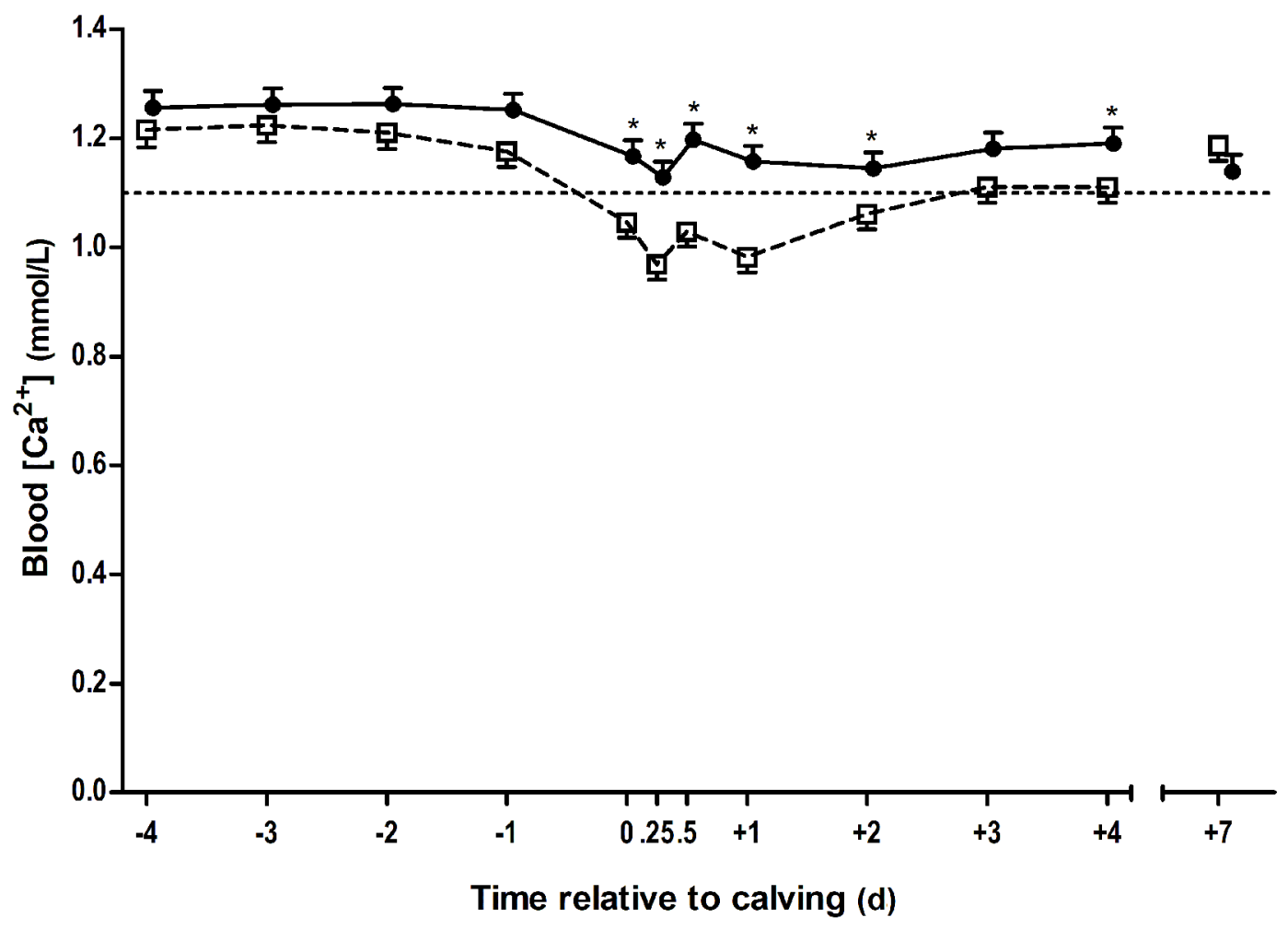

Figure 3. Least squares means $( \pm \mathrm{SEM})$ of blood ionized Ca concentration $\left(\left[\mathrm{Ca}^{2+}\right]\right)$ for adequate $\mathrm{P}$ (AP, dashed line, open squares) and low $\mathrm{P}$ (LP, solid line, closed circles) treatments. The horizontal dotted line represents the lower reference range for blood $\left[\mathrm{Ca}{ }^{2+}\right]$ in cattle (Wilms et al., 2019). Each treatment comprised 15 multiparous dairy cows fed a dry cow ration with either adequate (AP, $0.30 \% \mathrm{P}$ in $\mathrm{DM})$ or low $\mathrm{P}$ content (LP, $0.16 \% \mathrm{P}$ in DM) during the last 4 wk of gestation. Time points labeled with an asterisk differ significantly between groups $(P<$ 0.05). Time points of both treatments are slightly offset on the time axes to improve readability.

periparturient dairy cows. The results presented here show that P-restrictive feeding in late gestation indeed results in increased blood $\left[\mathrm{Ca}^{2+}\right]$ and plasma [TCa] for at least the first $4 \mathrm{~d}$ of lactation compared with cows fed diets with adequate $\mathrm{P}$ content. This positive effect was associated with numerically lower incidence rates of clinical and subclinical hypocalcemia in cows on restricted compared with cows on adequate P supply. Furthermore, SCH in P-deprived cows was diagnosed on 2 consecutive days at most, whereas half of the cows on adequate dietary $\mathrm{P}$ supply diagnosed with SCH had subnormal blood $\left[\mathrm{Ca}^{2+}\right]$ over a period of at least $3 \mathrm{~d}$ and thus were classified as chronically hypocalcemic. These results indicate that $\mathrm{P}$ restriction during the dry period tends not only to reduce the incidence of clinical and subclinical hypocalcemia but also to mitigate the severity and duration of periparturient hypocalcemia.

The $\mathrm{P}$ content of the LP treatment diet used in this experiment is considerably below current recommendations for diets of late-pregnant dry cows of $0.26 \%$ in DM (GfE, 2001; NRC, 2001). The development of hypophosphatemia in LP cows suggests that this feed- ing protocol indeed resulted in a state of negative $\mathrm{P}$ balance. Remarkably, the level of hypophosphatemia observed in the present study, with mean values in the range of $0.9 \mathrm{mmol} / \mathrm{L}$ before the physiological postparturient dip of the plasma $[\mathrm{Pi}]$ was considerably less pronounced than the mean values below $0.5 \mathrm{mmol} / \mathrm{L}$ reported by Cohrs et al. (2018), albeit the difference in dietary $\mathrm{P}$ content between the current and our previous study $[0.16 \% \mathrm{P}$ in $\mathrm{DM}$ here compared with $0.15 \%$ in DM in the study by Cohrs et al. (2018)] was marginal. Although it is probable that, in a state of negative $\mathrm{P}$ balance, even a small difference in the dietary P supply may have a more pronounced influence on extracellular $\mathrm{P}$ homeostasis than at a higher P supply level, we deem it likely that this difference is primarily attributable to the greater degree of day-to-day variation in feed composition observed in the present study, which was conducted in a field setting. These results indicate that limiting restrictive $\mathrm{P}$ feeding to late gestation does not measurably weaken the positive effect on the Ca homeostasis in the first week of lactation compared with feeding a P-deficient diet beyond the first week of lactation (Cohrs et al., 2018). 
Another study with the same objective of inducing a state of negative $\mathrm{P}$ balance in dry cows was unsuccessful in causing either hypophosphatemia or any sign suggestive of an activation of counter-regulation to a negative $\mathrm{P}$ balance when feeding a diet with $0.21 \% \mathrm{P}$ in $\mathrm{DM}$, which would be considered moderately $\mathrm{P}$ deficient for dry cows in their last weeks of gestation (NRC, 2001; Peterson et al., 2005). In this study animals had ad libitum access to feed with an average daily DMI of $17.8 \mathrm{~kg}$, corresponding to a daily $\mathrm{P}$ intake of over 37 $\mathrm{g} / \mathrm{d}$ (Peterson et al., 2005). Other studies investigating the effect of a restricted dietary $\mathrm{P}$ supply in dry cows combined either a marginal or a deficient $\mathrm{P}$ supply with a Ca supply several-fold above requirements, or did not disclose the amounts of feed or P consumed in the week before calving, making a comparison with the results reported here difficult (Barton et al., 1987; Puggaard et al., 2014).

In preparation for this experiment, we conducted a pilot study aiming at identifying the level of $\mathrm{P}$ restriction required to measurably trigger counter-regulation to a negative $\mathrm{P}$ balance in dry cows. Results of this experiment indicate that the daily $\mathrm{P}$ supply of an adult late-pregnant and nonlactating dairy cow needed to remain below $20 \mathrm{~g}$ of $\mathrm{P}$ per day for 2 wk or longer (Cohrs et al., 2021). Specifically, this pilot study identified an increase of plasma [CTX] relative to baseline of above $0.2 \mathrm{ng} / \mathrm{mL}$ as a potentially suitable indicator for activated bone mobilization in response to $\mathrm{P}$ deprivation. This result, which certainly requires confirmation in a larger study, implies that a diet with $0.15 \% \mathrm{P}$ in $\mathrm{DM}$ with a voluntary DMI intake of $16 \mathrm{~kg}$, corresponding to the average DMI of dry dairy cows at our research unit, would not be sufficiently low to induce a negative $\mathrm{P}$ balance. This was the rationale for the restricted feeding protocol in dry cows used here.

In this context, it should be noted that suggested $\mathrm{P}$ contents in dry cow rations are generally based on an estimated DMI of between 10.5 and $14.0 \mathrm{~kg}$ of DM, which is well below the true daily intake observed in a high-yielding dairy cow during the dry period (GfE, 2001; NRC, 2001). Our finding furthermore disagrees with the current practice of calculating dietary $\mathrm{P}$ requirements of dry cows based on the expected DMI,

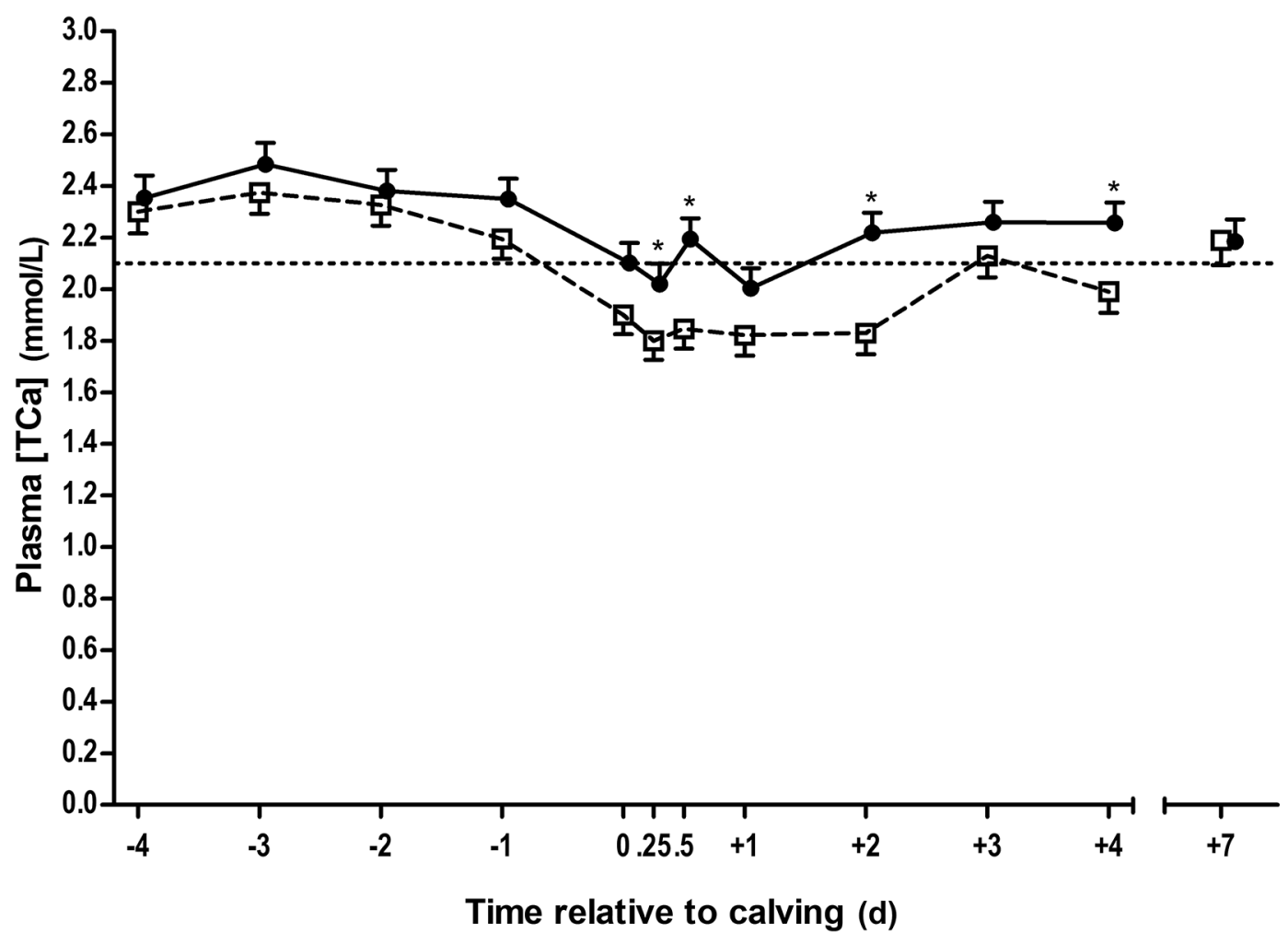

Figure 4. Least squares means $( \pm$ SEM) of plasma total Ca concentration ([TCa]) for adequate P (AP, dashed line, open squares) and low $\mathrm{P}$ (LP, solid line, closed circles) treatments. The horizontal dotted line represents the lower reference range for plasma [TCa] in cattle (Neves et al., 2017). Each treatment comprised 15 multiparous dairy cows fed a dry cow ration with either adequate (AP, $0.30 \% \mathrm{P}$ in DM) or low $\mathrm{P}$ content (LP, $0.16 \% \mathrm{P}$ in DM) during the last $4 \mathrm{wk}$ of gestation. Time points labeled with an asterisk differ significantly between treatments $(P$ $<0.05)$. Time points of both treatments are slightly offset on the time axes to improve readability. 
which is based on the concept that maintenance requirements for $\mathrm{P}$ are a function of DMI rather than body mass in ruminants (Spiekers et al., 1993).

Several field studies of the past decades have already reported an association between dietary $\mathrm{P}$ content during the dry period and the risk of milk fever (Julien et al., 1977; Lean et al., 2006). These studies specifically report an increased risk of periparturient hypocalcemia when feeding dry cow rations in excess of $0.30 \%$ $\mathrm{P}$ in $\mathrm{DM}$, which is still common practice in the dairy industry. The study reported here introduces the novel concept of inducing a negative $\mathrm{P}$ balance before calving by feeding rations with a dietary $\mathrm{P}$ content below current recommendations for dry dairy cows, similar to the concept of using low-Ca diets as a measure to mitigate the occurrence of clinical and subclinical hypocalcemia in fresh cows.

The plasma [Pi] of P-deprived cows in the days before calving was approximately half the concentration determined in cows on adequate $\mathrm{P}$ supply. Values in the range of 0.8 to $1.1 \mathrm{mmol} / \mathrm{L}$ in $\mathrm{LP}$ cows can be categorized as moderately hypophosphatemic but were not associated with overt clinical signs commonly as- sociated with hypophosphatemia, such as feed intake depression or decreased productivity (data not shown). Remarkably, subnormal plasma [Pi] antepartum did not mitigate the dip in plasma $[\mathrm{Pi}]$ at calving that is commonly observed in dairy cows. The sudden but short-lived decline of the plasma $[\mathrm{Pi}]$ within the first $24 \mathrm{~h}$ of calving even in healthy cows on adequate $\mathrm{P}$ supply is a well-documented physiological development that neither can be solely attributed to loss of $\mathrm{P}$ through the mammary gland nor is indicative of an inadequate P supply (Goff et al., 2002; Grünberg, 2014; Megahed et al., 2018). Producers and veterinarians do, however, observe this reduction in plasma $[\mathrm{Pi}]$ in fresh cows with concern, as it is widely believed to be associated with negative effects on health and productivity, particularly in high-yielding dairy cows. Reduced feed intake, hampered productivity and fertility, and even an increased risk of becoming a "downer cow" or developing postparturient hemoglobinuria, have been linked to hypophosphatemia in fresh cows (Ménard and Thompson, 2007; Grünberg, 2014). In the present experiment, with an observation period limited to the first $7 \mathrm{~d}$ of lactation, no indication of impaired health

Table 2. Results of repeated-measures ANOVA ( $P$-values) for plasma concentrations of CrossLaps ([CTX], Immunodiagnostic Systems GmbH), parathyroid hormone $([\mathrm{PTH}])$, and 1,25-dihydroxyvitamin $\mathrm{D}\left(\left[1,25-(\mathrm{OH})_{2} \mathrm{D}_{3}\right]\right)$ for cows on a dry cow ration with either adequate $(\mathrm{AP})$ or low (LP) $\mathrm{P}$ content, stratified by time relative to calving ${ }^{1}$

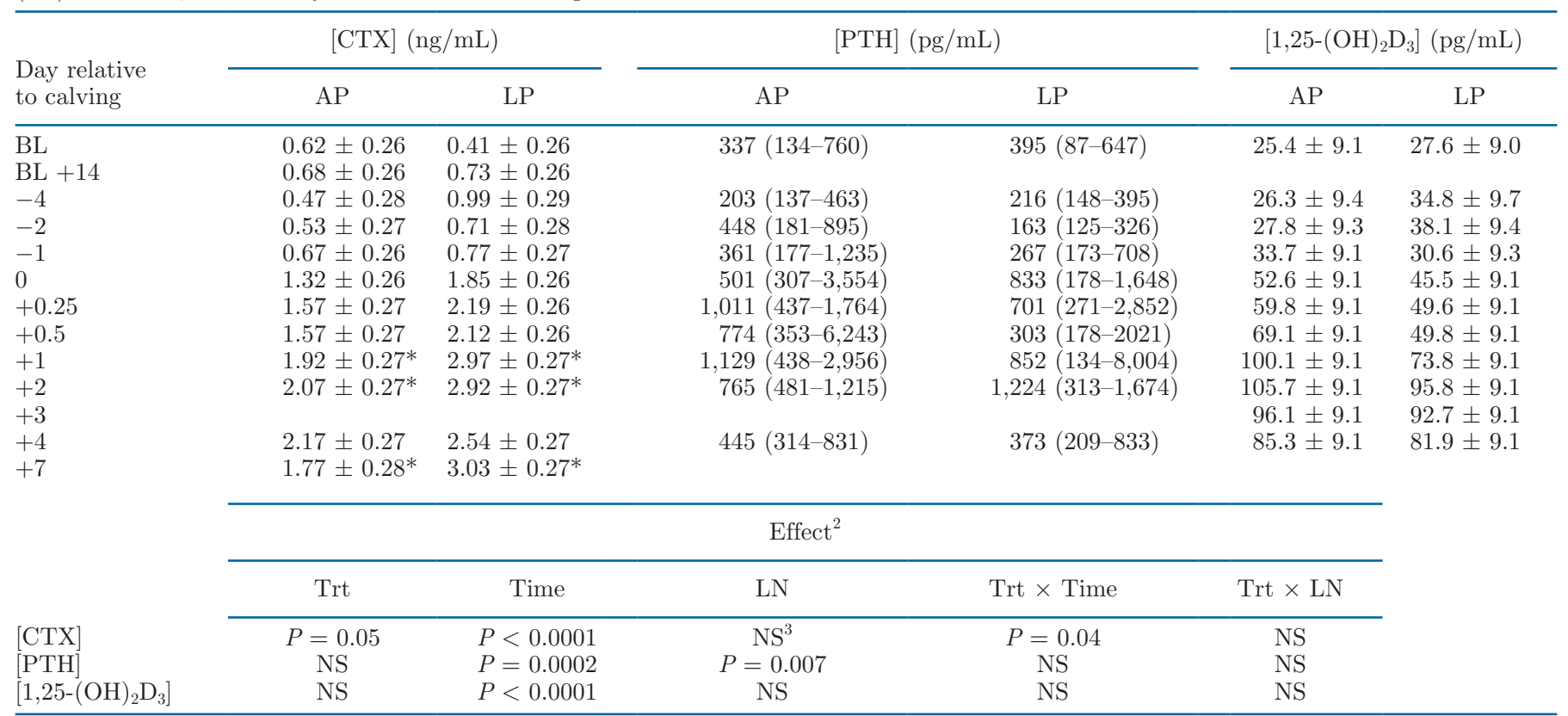

${ }^{1} \mathrm{BL}=$ baseline measurements, sampled at the end of the acclimation period; BL $+14=$ samples taken after 2 wk of feeding the experimental diets; $\mathrm{d} 0=$ date of calving; $\mathrm{d}+0.25, \mathrm{~d}+0.5=6$ and $12 \mathrm{~h}$ postpartum. Results are presented as $\mathrm{LSM} \pm \mathrm{SEM}$ or median and interquartile range (shown in parentheses). Each treatment comprised 15 multiparous dairy cows fed a dry cow ration with either adequate (AP, $0.30 \% \mathrm{P}$ in $\mathrm{DM}$ ) or low $\mathrm{P}$ content (LP, $0.16 \% \mathrm{P}$ in $\mathrm{DM})$ during the last 4 wk of gestation.

${ }^{2}$ Studied effects were treatment (Trt), time, lactation number $(\mathrm{LN})$, Trt $\times$ Time, and Trt $\times$ LN interactions.

${ }^{3} \mathrm{NS}=$ no significant effect.

*Significant difference between treatments at a specific time point $(P<0.05)$. 
was observed in cows on restricted dietary $\mathrm{P}$ supply for the last $4 \mathrm{wk}$ of gestation. Furthermore, none of the blood biochemical parameters included in this study, other than $\left[\mathrm{Ca}^{2+}\right]$, [TCa], and $[\mathrm{CTX}]$, revealed a significant treatment effect. Earlier studies, where dietary $\mathrm{P}$ deprivation was extended to 4 wk and longer into lactation, did, however, report important negative effects on DMI, productivity, and disease incidences (Puggaard et al., 2014; Grünberg et al., 2019). Protracted effects of $\mathrm{P}$ deprivation during the dry period potentially occurring later in lactation in the cows included in this study are currently being studied by our laboratory. No overt negative effects on health and productivity in experimental cows were apparent in the weeks following the conclusion of this study.

Mechanisms behind increased Ca concentrations associated with dietary $\mathrm{P}$ deprivation in transition dairy cows have been discussed previously (Kichura et al., 1982; Puggaard et al., 2014; Cohrs et al., 2018). Activation of osteoclast activity in response to $\mathrm{P}$ deprivation and the ensuing release of $\mathrm{Ca}$ and $\mathrm{P}$ from bone have been reported, but the relevance of this mechanism for the regulation of the $\mathrm{P}$ homeostasis has been questioned (Thompson et al., 1975; Kichura et al., 1982). A recent study investigating the influence of dietary $\mathrm{P}$ deprivation on bone mobilization in sheep showed that the gene expression related to CTX, as well as serum [CTX], increased in P-deprived sheep compared with sheep on an adequate P supply (Köhler et al., 2021). Although Cohrs et al. (2018) reported markedly higher plasma [CTX] in P-deprived cows already $2 \mathrm{~d}$ before calving, compared with cows on adequate $\mathrm{P}$ supply, differences were only numerically higher antepartum in LP cows in the present study, with differences between treatment reaching statistical significance only $1 \mathrm{~d}$ after calving. These results suggest that the more moderate hypophosphatemia observed in this experiment was associated with less pronounced activation of osteoclast activity in cows on restricted $\mathrm{P}$ supply compared with the study by Cohrs et al. (2018).

Although enhanced bone mobilization in states of $\mathrm{P}$ deficiency is well documented in cattle and other species, the underlying regulatory mechanism remains poorly understood (Baylink et al., 1971; Cohrs et al., 2018; Köhler et al., 2021). The secretion of PTH is generally reported to be decreased in P-deprived animals, which has been attributed to the concomitant increase of plasma $\mathrm{Ca}$ as osteoclast activity is increased and $\mathrm{Ca}$ and $\mathrm{P}$ are released from the bone matrix (Kichura et al., 1982). In the absence of sustained dietary $\mathrm{P}$ deprivation during the dry period, a state of simultaneous negative $\mathrm{P}$ and $\mathrm{Ca}$ balance at calving presents an extraordinary metabolic situation in dairy cows. With the use of a
P-deficient diet as fed to LP cows in this study, it is conceivable that hampered $\mathrm{PTH}$ secretion in response to $\mathrm{P}$ deprivation may result in impaired efficacy of the counter-regulatory circuits responding to periparturient hypocalcemia. The results from Cohrs et al. (2018), however, indicate that enhanced bone mobilization triggered by $\mathrm{P}$ deprivation results in elevated plasma Ca concentrations around parturition despite markedly lower plasma $[\mathrm{PTH}]$ around calving compared with cattle on adequate $\mathrm{P}$ supply. These findings, which have been corroborated by studies conducted on P-deficient breeder cows, suggest that bone mobilization in states of $\mathrm{P}$ deficiency is at least as efficacious in supplying the extracellular space with $\mathrm{Ca}$ as bone mobilization triggered by Ca deficiency, while being less dependent on or even entirely independent of PTH (Anderson et al., 2017). The results of the PTH analysis of the present study were inconclusive due to the unexpectedly large degree of intra- and interindividual variation.

In the current study, dietary $\mathrm{P}$ deprivation did not result in significant differences in plasma $\left[1,25-(\mathrm{OH})_{2} \mathrm{D}_{3}\right]$ between the LP and AP cows, which again is in agreement with the results from Cohrs et al. (2018). This further strengthens the assumption that it is indeed bone mobilization rather than enhanced intestinal $\mathrm{Ca}$ absorption triggered by $\left[1,25-(\mathrm{OH})_{2} \mathrm{D}_{3}\right]$ that results in the improved $\mathrm{Ca}$ status in $\mathrm{P}$-deprived periparturient cows.

To achieve the goal of inducing a negative $\mathrm{P}$ balance in late gestation, a restricted feeding protocol was used in this experiment. Although the study was designed to control for the effect of restricted DMI in the dry period, restricting DMI in close-up cows is undesirable in practice, and has the potential to also affect the $\mathrm{Ca}$ balance around parturition. Balanced dry cow rations with $0.15 \% \mathrm{P}$ in DM and below are extremely difficult to formulate with standard feed ingredients commonly used in Europe and the Americas, which was the reason for the implementation of the restricted feeding protocol. This difficulty in inducing a negative $\mathrm{P}$ balance in dry cows on the one hand underscores that the risk of insufficient $\mathrm{P}$ supply during the dry period when using standard feed ingredients of the geographic regions mentioned above is marginal, and on the other hand indicates that, should dietary $\mathrm{P}$ deprivation of dry cows become an established option to reduce the risk of $\mathrm{SCH}$ in early lactation, the use of P-binding compounds in these diets such as zeolites may be required.

Another limitation of this study resulted from the decision to treat study animals with clinical hypocalcemia in an early stage, thus before becoming recumbent. Because blood samples were only included until immediately before treatment, more samples of hypocalcemic 
cows had to be excluded from the analysis than if animals had been treated only after becoming recumbent. This is likely to have resulted in an underestimation of the treatment effect on Ca homeostasis in this experiment.

In conclusion, restricted dietary $\mathrm{P}$ supply during the last 4 wk of gestation was effective in improving Ca homeostasis in high-yielding dairy cows during the first days of lactation. The positive effect seems to be primarily attributable to enhanced bone mobilization in periparturient cows in negative $\mathrm{P}$ balance.

\section{ACKNOWLEDGMENTS}

The authors acknowledge the assistance of Christian Koch, Educational and Research Centre for Animal Husbandry, Hofgut Neumühle (Münchweiler an der Alsenz, Germany), in formulating the experimental rations, of the staff of the dairy unit of Hofgut Neumühle for their dedicated technical assistance, and of Kathrin Hansen, Institute of Physiology and Cell Biology, University of Veterinary Medicine Hannover (Hanover, Germany), for the dedicated laboratory work. The feed additive monoammonium phosphate was generously provided by Aliphos Rotterdam BV (Rotterdam, The Netherlands). The authors furthermore acknowledge the financial support of the H. Wilhelm Schaumann Foundation (Hamburg, Germany) through a graduate student grant. The authors have not stated any conflicts of interest.

\section{REFERENCES}

Anderson, S. T., L. J. Kidd, M. A. Benvenutti, M. T. Fletcher, and R. M. Dixon. 2017. New candidate markers of phosphorus status in beef breeder cows. Anim. Prod. Sci. 57:2291-2303. https://doi .org/10.1071/AN17363.

Barton, B. A., N. A. Jorgensen, and H. F. Deluca. 1987. Impact of prepartum dietary phosphorus intake on calcium homeostasis at parturition. J. Dairy Sci. 70:1186-1191. https://doi.org/10.3168/ jds.S0022-0302(87)80130-3.

Baylink, D., J. Wergedal, and M. Stauffer. 1971. Formation, mineralization, and resorption of bone in hypophosphatemic rats. J. Clin. Invest. 50:2519-2530. https://doi.org/10.1172/JCI106752.

Block, E. 1984. Manipulating dietary anions and cations for prepartum dairy cows to reduce incidence of milk fever. J. Dairy Sci. 67:29392948. https://doi.org/10.3168/jds.S0022-0302(84)81657-4.

Cohrs, I., M. R. Wilkens, and W. Grunberg. 2018. Short communication: Effect of dietary phosphorus deprivation in late gestation and early lactation on the calcium homeostasis of periparturient dairy cows. J. Dairy Sci. 101:9591-9598. https://doi.org/10.3168/ jds.2018-14642.

Cohrs, I., M. R. Wilkens, S. Wächter, L. Golbeck, T. Scheu, and W. Grünberg. 2021. Estimation of dietary phosphorus requirements of dairy cows during the dry period by means of a biomarker for bone resorption. Page 54 in Proc. Soc. Nutr. Physiol. DLG-Verlag $\mathrm{GmbH}$.

Constable, P. D., K. W. Hinchcliff, S. H. Done, and W. Grünberg. 2016a. Metabolic and endocrine diseases. Pages 1662-1757 in Vet- erinary Medicine: A Textbook of the Diseases of Cattle, Horses, Sheep, Pigs, and Goats. 11th ed. Elsevier.

Constable, P. D., K. W. Hinchcliff, S. H. Done, and W. Grünberg. 2016b. Reference laboratory values. Pages 2217-2219 in Veterinary Medicine: A Textbook of the Diseases of Cattle, Horses, Sheep, Pigs, and Goats. 11th ed. Elsevier.

GfE. 2001. Ausschuss für Bedarfsnormen der Gesellschaft für Ernährungsphysiologie, Nr. 8. Empfehlungen zur Energie- und Nährstoffversorgung der Milchkühe und Aufzuchtrinder. DLGVerlag.

Goff, J. P., K. Kimura, and R. L. Horst. 2002. Effect of mastectomy on milk fever, energy, and vitamins A, E, and $\beta$-carotene status at parturition. J. Dairy Sci. 85:1427-1436. https://doi.org/10.3168/ jds.S0022-0302(02)74210-0.

Grünberg, W. 2014. Treatment of phosphorus balance disorders. Vet. Clin. North Am. Food Anim. Pract. 30:383-408. https://doi.org/ 10.1016/j.cvfa.2014.03.002.

Grünberg, W., P. Scherpenisse, I. Cohrs, L. Golbeck, P. Dobbelaar, L. M. van den Brink, and I. D. Wijnberg. 2019. Phosphorus content of muscle tissue and muscle function in dairy cows fed a phosphorus-deficient diet during the transition period. J. Dairy Sci. 102:4072-4093. https://doi.org/10.3168/jds.2018-15727.

Grünberg, W., P. Scherpenisse, P. Dobbelaar, M. J. Idink, and I. D. Wijnberg. 2015. The effect of transient, moderate dietary phosphorus deprivation on phosphorus metabolism, muscle content of different phosphorus-containing compounds, and muscle function in dairy cows. J. Dairy Sci. 98:5385-5400. https://doi.org/10.3168/ jds.2015-9357.

Julien, W. E., H. R. Conrad, and D. R. Redman. 1977. Influence of dietary protein on susceptibility to alert downer syndrome. J. Dairy Sci. 60:210-215. https://doi.org/10.3168/jds.S0022-0302(77)83856 -3 .

Kichura, T. S., R. L. Horst, D. C. Beitz, and E. T. Littledike. 1982. Relationships between prepartal dietary calcium and phosphorus, vitamin $\mathrm{D}$ metabolism, and parturient paresis in dairy cows. J. Nutr. 112:480-487. https://doi.org/10.1093/jn/112.3.480

Köhler, O. M., W. Grünberg, N. Schnepel, A. S. Muscher-Banse, A. Rajaeerad, J. Hummel, G. Breves, and M. R. Wilkens. 2021. Dietary phosphorus restriction affects bone metabolism, vitamin D metabolism and rumen fermentation traits in sheep. J. Anim. Physiol. Anim. Nutr. (Berl.) 105:35-50. https://doi.org/10.1111/ jpn.13449.

Lean, I. J., P. J. DeGaris, D. M. McNeil, and E. Block. 2006. Hypocalcemia in dairy cows: Meta-analysis and dietary cation anion difference theory revisited. J. Dairy Sci. 89:669-684. https://doi .org/10.3168/jds.S0022-0302(06)72130-0.

Martinez, N., C. A. Risco, F. S. Lima, R. S. Bisinotto, L. F. Greco, E. S. Ribeiro, F. Maunsell, K. Galvao, and J. E. P. Santos. 2012. Evaluation of peripartal calcium status, energetic profile, and neutrophil function in dairy cows at low or high risk of developing uterine disease. J. Dairy Sci. 95:7158-7172. https://doi.org/10 $.3168 /$ jds.2012-5812.

McArt, J. A. A., and R. C. Neves. 2020. Association of transient, persistent, or delayed subclinical hypocalcemia with early lactation disease, removal, and milk yield in Holstein cows. J. Dairy Sci. 103:690-701. https://doi.org/10.3168/jds.2019-17191.

Megahed, A. A., M. W. H. Hiew, S. A. El Badawy, and P. D. Constable. 2018. Plasma calcium concentrations are decreased at least 9 hours before parturition in multiparous Holstein-Friesian cattle in a herd fed an acidogenic diet during late gestation. J. Dairy Sci. 101:1365-1378. https://doi.org/10.3168/jds.2017-13376.

Ménard, L., and A. Thompson. 2007. Milk fever and alert downer cows: Does hypophosphatemia affect the treatment response? Can. Vet. J. 48:487-491.

Neves, R. C., B. M. Leno, K. D. Bach, and J. A. A. McArt. 2018 Epidemiology of subclinical hypocalcemia in early-lactation Holstein dairy cows: The temporal associations of plasma calcium concentration in the first 4 days in milk with disease and milk production. J. Dairy Sci. 101:9321-9331. https://doi.org/10.3168/ jds.2018-14587. 
Neves, R. C., B. M. Leno, T. Stokol, T. R. Overton, and J. A. A. McArt. 2017. Risk factors associated with postpartum subclinical hypocalcemia in dairy cows. J. Dairy Sci. 100:3796-3804. https:// doi.org/10.3168/jds.2016-11970.

NRC. 2001. Nutrient Requirements of Dairy Cattle. 7th rev. ed. Natl. Acad. Press.

Peterson, A. B., M. W. Orth, J. P. Goff, and D. K. Beede. 2005. Periparturient responses of multiparous Holstein cows fed different dietary phosphorus concentrations prepartum. J. Dairy Sci. 88:35823594. https://doi.org/10.3168/jds.S0022-0302(05)73043-5.

Puggaard, L., P. Lund, A. Liesegang, and J. Sehested. 2014. Long term effect of reduced dietary phosphorus on feed intake and milk yield in dry and lactating dairy cows. Livest. Sci. 159:18-28. https://doi .org/10.1016/j.livsci.2013.10.009.

Spiekers, H., R. Brintrup, M. Balmelli, and E. Pfeffer. 1993. Influence of dry matter intake on faecel phosphorus losses in dairy cows fed rations low in phosphorus. J. Anim. Physiol. Anim. Nutr. (Berl.) 69:37-43. https://doi.org/10.1111/j.1439-0396.1993.tb00788.x.

Thilsing-Hansen, T., R. J. Jorgensen, J. M. D. Enemark, and T. Larsen. 2002. The effect of zeolite A supplementation in the dry period on periparturient calcium, phosphorus, and magnesium homeostasis. J. Dairy Sci. 85:1855-1862. https://doi.org/10.3168/jds.S0022 $-0302(02) 74259-8$
Thompson, E. R., D. J. Baylink, and J. E. Wergedal. 1975. Increases in number and size of osteoclasts in response to calcium or phosphorus deficiency in the rat. Endocrinology 97:283-289. https:// doi.org/10.1210/endo-97-2-283.

USDA. 2002. Part I: Reference of Dairy Cattle Health and Management Practices in the United States, 2002. USDA:APHIS:VS CEAH, National Animal Health Monitoring System.

Venjakob, P. L., L. Pieper, W. Heuwieser, and S. Borchardt. 2018 Association of postpartum hypocalcemia with early-lactation milk yield, reproductive performance, and culling in dairy cows. J. Dairy Sci. 101:9396-9405. https://doi.org/10.3168/jds.2017-14202.

Weissbach, F., and S. Kuhla. 1995. Substance losses in determining the dry matter content of silage and green fodder: Arising errors and possibilities of correction. Übers. Tierernähr. 23:189-214.

Wilms, J., G. Wang, J. Doelman, M. Jacobs, and J. Martin-Tereso. 2019. Intravenous calcium infusion in a calving protocol disrupts calcium homeostasis compared with an oral calcium supplement. J. Dairy Sci. 102:6056-6064. https://doi.org/10.3168/jds.2018-15754.

Yilmaz, O., and T. Karapinar. 2019. Evaluation of the i-STAT analyzer for determination of ionized calcium concentrations in bovine blood. Vet. Clin. Pathol. 48:31-35. https://doi.org/10.1111/vcp .12705 . 